\title{
Physicochemical properties and shelf-life of low-fat pork sausages wrapped with active film manufactured by sodium alginate and cherry tomato powder
}

\author{
Zhuang Zhuang Qiu' and Koo Bok Chin ${ }^{1, *}$
}

\author{
* Corresponding Author: Koo Bok Chin \\ Tel: +82-62-530-2121, Fax: +82-62-530-2129, \\ E-mail: kbchin@chonnam.ac.kr \\ ${ }^{1}$ Department of Animal Science, Chonnam National \\ university, Gwangju, 61186, Korea \\ ORCID \\ Zhuang Zhuang Qiu \\ https://orcid.org/0000-0002-1501-2034 \\ Koo Bok Chin \\ https://orcid.org/0000-0002-8062-6331
}

Submitted Feb 26, 2020; Revised Apr 25, 2020; Accepted May 6, 2020
Objective: This study was carried out to investigate physicochemical properties, and antioxidant and antimicrobial activities of low-fat sausages (LFSs) covered with sodium alginate (SA) film alone and with powder film (TSA-film) formed by cross-linking cherry tomato powder (CTP) and SA with calcium chloride $\left(\mathrm{CaCl}_{2}\right)$.

Methods: Sausages covered with the biodegradable film were assessed based on the measurement of $\mathrm{pH}$, color $\left(\mathrm{L}^{*}, \mathrm{a}^{*}, \mathrm{~b}^{*}\right)$, proximate analysis, expressive moisture $(\mathrm{EM})$, texture profile analysis, total plate counts (TPC), violet red bile, and 2-Thiobarbituric acid reactive substances (TBARS) during storage under refrigeration. LFSs wrapped with TSA-film were compared with those wrapped with SA-film and without film (control) during storage at $10^{\circ} \mathrm{C}$ for 35 days.

Results: The LFSs covered with the mixed film had lower $\mathrm{pH}$, lightness $\left(\mathrm{L}^{*}\right), \mathrm{EM} \%$, TBARS, and TPC, but lower yellowness $\left(b^{\star}\right)$ and hardness values than those wrapped with TSA-film alone.

Conclusion: Lipid oxidation and microbial growth was retarded in sausages covered with biodegradable films, especially multiple films as compared to single film, thereby resulting in extended shelf-life of the LFSs.

Keywords: Low-fat Sausage; Active Film; Cherry Tomato; Physicochemical Properties

\section{INTRODUCTION}

In recent years, developments in biodegradable polymer packaging films have been extensively studied. Environmental and food safety issues have resulted in increased interest in the exploitation of packaging materials obtained from natural resources to extend the shelflife of foodstuffs. Moreover, traditionally used synthetic packaging materials had problems related to the food safety issues which necessitate the need for replacement of these with natural resources. The concerns of health-conscious consumers are emerging about food safety issues and therefore, current research is focused on the use of natural, active, edible, and biodegradable packaging materials for extension of shelf of low-fat sausages (LFSs) [1].

Alginate is a promising natural polymer that has been used widely for controlled release of bioactive compounds due to its peculiar characteristics, such as biocompatibility, biodegradability, and remarkable ability to form hydrogels [2]. Its matrix can be hydrated to form a gelatinous layer under relatively mild chemical conditions; also cross-linking of alginate matrix with multivalent cations, such as calcium, has been reported [3]. Alginate could be divided into two broad categories: homopolymeric (M-M and G-G) and heteropolymeric (MG or GM) substances [4]. Binding of $\mathrm{Ca}^{2+}$ to alginate is carried out by the 
three-step process involving mono-complexation, dimerization, and subsequent combination of dimers [5]. The diffusion of small molecules is facilitated by nonporous alginate gel (pore size $\sim 5 \mathrm{~nm}$ ) [6].

Cherry tomato has been one of the most widely consumed food commodities. They are rich source of lycopene, polyphenols, carotenoids, minerals, vitamin $\mathrm{C}$, and small quantities of other vitamins [7]. Among them, lycopene is the most abundant pigment which imparts red color to tomatoes [8]. Lycopene along with carotenoids provides provitamin and antioxidant properties; furthermore, rich nutritional profile and delicious taste have drawn attention towards this widely consumed fruit over the past years $[9,10]$. Tomato powder is produced by drying methods to reduce internal moisture to proper amount. They are an ideal candidate as additive to a variety of food products: soups, sauces, marinades, meat products, dips, cereal products, fruit purees, and snacks owing to their characteristic color, flavor, and water binding properties [11]. Nutrient degradation has been reported to occur during drying of fresh fruits and vegetables $[12,13]$. However, conversion of tomatoes into powder form has several advantages like shelf stability and wide applicability to different food products, mineral mixtures, supplements, and anti-aging products [11]. Fernández-Pan et al [14] evaluated the antimicrobial effect of edible coatings and demonstrated effectiveness in case of chicken breast with regard to control of microbial growth than other common preservatives. Edible films in combination with essential oils have been employed to achieve improvement in preservation and enhancement of shelf-life. In order to ensure safety and preservation of product quality during storage, controlled release of active ingredients is an important phenomenon in application of functional packaging. In current study, we added $1 \%$ cherry tomato powder (CTP) to sodium alginate (SA) and the effects of active film on physicochemical properties of LFSs, functional compounds, and the extension of shelf-life were assessed.

However, there exist only a few studies on the application of composite film for packaging of meat products. Thus, the objective of this study is to evaluate physicochemical properties and antioxidant activity of alginate films added with CTP as influenced by cross-linking agent (calcium chloride). The active film was found to be beneficial due to its potent antimicrobial and preservation effects in terms of extending the shelf life of foodstuffs.

\section{MATERIALS AND METHODS}

\section{Cooked pork model sausages preparation}

Pork hams (LandracexYorkshire, grade A) were purchased from the local market (Samho Co., Gwangju, Korea). After taking off the lean and excess connective tissue, the meat was ground and mixed with non-meat ingredients ( $1.3 \%$ salt, $0.4 \%$ sodium tripolyphosphate, $0.25 \%$ cured blend, $0.05 \%$ sodium erythorbate, and $1 \%$ soy protein isolate). The meat batter was stuffed into polyvinylidene dichloride film and cooked in a water bath at $75^{\circ} \mathrm{C}$ for $30 \mathrm{~min}$. After chilling, LFSs were coated with films and stored at $10^{\circ} \mathrm{C}$ under refrigeration for 35 days.

\section{Film preparation}

The SA was purchased from the Tureban company (Goyang, Korea). The CTP was purchased from seed fruit and vegetable products company (Dunhuang, Gansu, China). A film-forming solution including SA (2\%) was dissolved in calcium chloride solution $(0.01 \mathrm{~g} / 100 \mathrm{~mL})$ with glycerol (same amount as SA) and dried in a dry-oven at $50^{\circ} \mathrm{C}$ for $24 \mathrm{~h}$. Cross-linking was completed by pouring $50 \mathrm{~mL}$ of calcium chloride into film for $30 \mathrm{~s}$ followed by drying at room temperature for $6 \mathrm{~h}$. Except that, 1\% CTP was additionally added to prepare for a tomato SA film.

\section{$\mathrm{pH}$, color value, and microbial count}

The $\mathrm{pH}$ of samples was determined randomly with a $\mathrm{pH}$ meter (Mettle-Toledo, Schwarzenbach, Switzerland). The color values consisting of lightness (Commission Internationale de l'Eclairage $\left.[\mathrm{CIE}] \mathrm{L}^{\star}\right)$, redness $\left(\mathrm{CIE} \mathrm{a}^{\star}\right)$, and yellowness $\left(\mathrm{CIE} \mathrm{b}^{*}\right)$ of samples were measured by the color reader (Model CR-10. Minolta, Tokyo, Japan). For the microbial count, $10 \mathrm{~g}$ ground sample was mixed with $90 \mathrm{~mL}$ saline water $(0.9 \%)$ using a Stomacher Lab Blender and serial dilutions were prepared. Then, about $0.1 \mathrm{~mL}$ of diluted sample was dispersed onto the surface of violet red bile (VRB) and total plate count (TPC) agar (Bingol and Bostan [15]). Subsequently, VRB and TPC agars were incubated at $37^{\circ} \mathrm{C}$ for $24 \mathrm{~h}$.

\section{Proximate composition}

Moisture, crude fat content, and fat content were assessed at $0,3,714,21,28$, and 35 days by the method of AOAC [16]. Crude fat content was determined by the Soxhlet extraction method and crude protein analysis was carried out by following Kjeldahl technique.

\section{Texture profile analysis}

Universal Testing Machine (Model 3344, Canton, MA, USA) was used to perform texture profile analysis (TPA) according to the method described by Bourne [17]. Sausage samples (1.30 cm length and $1.30 \mathrm{~cm}$ diameter) were compressed with a $500-\mathrm{N}$ load cell at operational speed of $300 \mathrm{~mm} / \mathrm{min}$. TPA values were expressed in terms of hardness (gf), springiness $(\mathrm{cm})$, gumminess, chewiness, and cohesiveness of LFSs.

\section{Expressible moisture}

Approximately $1.5 \mathrm{~g}$ of sample was wrapped in $3 / 4$ filter paper (one piece of filter paper was separated into 4 pieces uni- 
formly). Then, the sample was centrifuged (3,000 rpm) for 15 min (VS- 5000N, Vision Scientific Co. Ltd., Bucheon, Korea). Weight of both filter paper and samples was measured again. The expressible moisture (EM) content of samples was calculated as follows:

$$
\operatorname{EM}(\%)=\Delta \mathrm{T} \times 100 / \mathrm{A}
$$

$\Delta \mathrm{T}$ was the Thimble weight difference before and after centrifugation. A was the initial weight of the sample.

\section{Thiobarbituric acid reactive substances}

The oxidative rancidity was evaluated based on the thiobarbituric acid reactive substances (TBARS) value [18]. Each sample was mixed with $2.5 \%$ trichloroacetic acid $(3 \mathrm{~mL})$ and $1 \%$ 2 -thiobarbituric acid $(17 \mathrm{~mL})$ in a cap tube. Then, tubes were put into $90^{\circ} \mathrm{C}$ boiling water bath for $30 \mathrm{~min}$. Next, supernatant of each solution was mixed with $5 \mathrm{~mL}$ chloroform and centrifuged at 2,000 rpm for $5 \mathrm{~min}$ (VS-5000N, Vision Scientific Co. Ltd., Korea). Subsequently, approximately $3 \mathrm{~mL}$ petroleum was added to each supernatant and further centrifuged. Finally, clear solutions were analyzed by spectrophotometer (UV-1601, Shimadzu, Kyoto, Japan) at a wavelength of 532 $\mathrm{nm}$.

\section{Statistical analysis}

The data on the effects of three different treatments during 35 days of storage at $10^{\circ} \mathrm{C}$ on physicochemical properties and antioxidant activities of LFSs were collected and subjected to two-way analysis of variance with treatments and storage time as factors using SPSS 21.0 program for windows. If the interaction between two factors were significant, then the data were separated out by treatment and storage time, which was analyzed at the significant level of 0.05 , respectively.

\section{RESULTS AND DISCUSSION}

\section{$\mathrm{pH}$ and color}

$\mathrm{pH}$ and color values of LFSs are shown in Table 1. During storage, no changes in $\mathrm{pH}$ values of pooled control and treatments were observed during storage time, since the treated sausages and control didn't detect microbial counts until 28 days of storage $\left(<2^{\mathrm{e}} \mathrm{Log}\right.$ colony-forming unit [CFU]/g). LFSs wrapped with $2 \%$ SA film were same $\mathrm{pH}$ as LFSs without film (control [CTL]), but LFSs wrapped with 2\% SA and 1\% CTP film (TSA film) were lower $\mathrm{pH}$ than those of control, which might be due to the addition of tomato powder. Although the $\mathrm{pH}$ of sausage decreased with the wrapping with TSA-film statistically, the differences in $\mathrm{pH}$ was not enough to affect the sausage quality of sausage since the difference in $\mathrm{pH}$ was minimal. However, Deda et al [19] reported that the
Table 1. pH and color of low-fat pork sausages wrapped with SA and TSA films

\begin{tabular}{lcccc}
\hline Parameters & $\mathbf{p H}$ & CIE $^{*}$ & CIE a* & CIE b $^{*}$ \\
\hline Treatments $^{1)}$ & & & & \\
CTL & $6.06^{\mathrm{A}}$ & $73.71^{\mathrm{A}}$ & $10.70^{\mathrm{A}}$ & $5.91^{\mathrm{B}}$ \\
SA & $6.00^{\mathrm{AB}}$ & $73.2^{\mathrm{AB}}$ & $10.94^{\mathrm{A}}$ & $6.10^{\mathrm{B}}$ \\
TSA & $5.95^{\mathrm{B}}$ & $72.79^{\mathrm{B}}$ & $10.94^{\mathrm{A}}$ & $7.15^{\mathrm{A}}$ \\
Days & & & & \\
0 & $6.08^{\mathrm{a}}$ & $73.80^{\mathrm{a}}$ & $10.20^{\mathrm{c}}$ & $5.70^{\mathrm{c}}$ \\
3 & $5.99^{\mathrm{a}}$ & $73.38^{\mathrm{a}}$ & $10.40^{\mathrm{bc}}$ & $6.28^{\mathrm{abc}}$ \\
7 & $5.99^{\mathrm{a}}$ & $72.98^{\mathrm{a}}$ & $10.91^{\mathrm{abc}}$ & $6.10^{\mathrm{bc}}$ \\
14 & $6.01^{\mathrm{a}}$ & $72.68^{\mathrm{a}}$ & $10.98^{\mathrm{abc}}$ & $6.9^{\mathrm{a}}$ \\
21 & $6.01^{\mathrm{a}}$ & $73.18^{\mathrm{a}}$ & $11.20^{\mathrm{ab}}$ & $6.2^{\mathrm{bc}}$ \\
28 & $5.97^{\mathrm{a}}$ & $73.50^{\mathrm{a}}$ & $10.92^{\mathrm{abc}}$ & $6.42^{\mathrm{ab}}$ \\
35 & $5.97^{\mathrm{a}}$ & $73.22^{\mathrm{a}}$ & $11.40^{\mathrm{a}}$ & $6.53^{\mathrm{ab}}$ \\
\hline
\end{tabular}

CIE L*, lightness; CIE a*, redness; CIE b*, yellowness.

1) CTL, low fat sausages without film; $S A$, low fat sausages wrapped with $2 \%$ sodium alginate film; TSA, low fat sausages wrapped with $2 \%$ sodium alginate and $1 \%$ cherry tomato powder film.

${ }^{a-c}$ Mean with a different superscript in the same treatment were different $p<0.05$.

${ }^{A}, \mathrm{~B}$ Mean with a different superscript in the same storage days were different $p<0.05$.

$\mathrm{pH}$ reduction of frankfurter containing tomato paste was a result of an increase in lactic bacteria during storage. Surface color is the most important factors affecting consumer acceptance, purchasing decisions, and satisfaction. Sausage color values were primarily related to the film. LFSs with TSA film had lower lightness $\left(L^{*}\right)$ value, but higher yellowness $\left(b^{*}\right)$ value than CTL. Redness $\left(\mathrm{a}^{*}\right)$ values of all treatments exhibited no change regardless of wrapping. Based on the results, it was apparent that improvement in red and yellow color was due to the wrapped films, which led to increased preference of consumers for the products. Yuan et al [20] reported that chitosan films with added pomegranate peel extracts reduced the lightness and increased the redness. The increment of yellowness was affected by the lycopene in tomato powder, which imparted a peculiar red color [21]. During storage time, the redness and yellowness trended to increase, but lightness didn't change. Candogan [21] did the similar study on beef patties added with different levels of tomato paste and he found that during storage, lightness and redness of patties added with tomato paste decreased but yellowness increased. He also reported that changes of color values were due to antioxidant activities of lycopene and the pigments present inside tomato paste.

\section{Proximate analysis}

Crude fat, crude protein, and moisture of CTL, SA, and TSA were $2.05,2.23$, and $2.26 ; 16.30,17.04$, and $17.45 ; 80.3,78.8$, and 78.6, respectively (Table 2). During the storage period, moisture and crude fat contents (\%) exhibited no differences, except for a gradual decrease in crude protein level. Although moisture and crude fat contents (\%) of all treatments were 
Table 2. Proximate composition low-fat pork sausages wrapped with film of SA and TSA

\begin{tabular}{cccc}
\hline \multirow{2}{*}{ Items } & \multicolumn{3}{c}{ Proximate analysis (\%) } \\
\cline { 2 - 4 } & Moisture & Crude fat & Crude protein \\
\hline Treatments $^{1)}$ & & & \\
CTL & $80.3^{\mathrm{A}}$ & $2.05^{\mathrm{A}}$ & $16.30^{\mathrm{B}}$ \\
SA & $78.8^{\mathrm{A}}$ & $2.23^{\mathrm{A}}$ & $17.04^{\mathrm{AB}}$ \\
TSA & $78.6^{\mathrm{A}}$ & $2.26^{\mathrm{A}}$ & $17.45^{\mathrm{A}}$ \\
Days & & & \\
0 & $80.4^{\mathrm{a}}$ & $2.20^{\mathrm{a}}$ & $17.99^{\mathrm{a}}$ \\
3 & $80.1^{\mathrm{a}}$ & $2.03^{\mathrm{a}}$ & $17.48^{\mathrm{ab}}$ \\
7 & $79.2^{\mathrm{a}}$ & $2.05^{\mathrm{a}}$ & $17.30^{\mathrm{abc}}$ \\
14 & $79.5^{\mathrm{a}}$ & $2.40^{\mathrm{a}}$ & $16.96^{\mathrm{abc}}$ \\
21 & $77.9^{\mathrm{a}}$ & $1.99^{\mathrm{a}}$ & $16.45^{\mathrm{bc}}$ \\
28 & $78.9^{\mathrm{a}}$ & $2.22^{\mathrm{a}}$ & $16.35^{\mathrm{bc}}$ \\
35 & $78.8^{\mathrm{a}}$ & $2.38^{\mathrm{a}}$ & $15.99^{\mathrm{c}}$ \\
\hline
\end{tabular}

1) $\mathrm{CTL}$, low fat sausages without film; $S A$, low fat sausages wrapped with $2 \%$ sodium alginate film; TSA, low fat sausages wrapped with $2 \%$ sodium alginate and $1 \%$ cherry tomato powder film.

${ }^{a-c}$ Mean with a different superscript in the same treatment were different $p<0.05$.

${ }^{A, B}$ Mean with a different superscript in the same storage days were different $p<0.05$.

almost similar, regardless of wrapped films, protein content (\%) of LFSs wrapped with TSA film was higher than CTL and similar to LFSs wrapped with SA film; However, no differences in protein content (\%) was observed between CTL and LFSs wrapped with SA film ( $p>0.05)$. Elbakheet et al [22] reported that significant differences in fat content, ash content, and fiber content (\%) were not observed among different samples during storage. Also, protein content, fat content, ash content, and crude fiber content exhibited an increase with increased addition of replacement of wheat germ flour. In- creased protein content (\%) in LFSs wrapped with film was observed, especially in LFSs wrapped with TSA film. However, moisture or fat content (\%) was not different among the different treatments. Based on proximate analyses, it can be concluded that LFSs wrapped with film affected the proximate analyses due to water absorption from sausages by the film thereby, resulting in increased protein content. On the other hand, no changes in fat (\%) were observed, since the sausages had very low-fat content (\%).

\section{Texture profile analyses}

The results of texture profile analyses of LFSs during storage are shown in Table 3. LFSs wrapped with the film were harder than CTL, but those wrapped with TSA exhibited texture similar to the ones wrapped with SA. Ruiz-Ramírez et al [23] reported that hardness of textural was affected by $\mathrm{pH}$ and water content. In this study, the increases in hardness (gf) could be explained based on lower expressive moisture (Figure 1A) and $\mathrm{pH}$ (Table 1). Additionally, it has been widely recognized that water absorption by film affects textural hardness (gf). The water content in LFSs was absorbed by the film thereby resulting in increased hardness (gf). However, springiness $(\mathrm{mm})$, gumminess $(\mathrm{kg} / \mathrm{mm})$, chewiness $(\mathrm{kg} / \mathrm{mm}$ ), and cohesiveness (ratio) of all LFSs were not different among the treatments. Sánchez-Ortega et al [24] found that films could extend the shelf life because physicochemical properties (such as texture, moisture) of meat or meat products changed due to the gas barrier properties of film. They also reported that application of film also changed the sensory evaluation due to the changed physicochemical properties of the sausages. Our study was agreement with theirs and film or coating technique should increase the shelf

Table 3. Texture profile analyses of low-fat pork sausages wrapped with SA and TSA films

\begin{tabular}{|c|c|c|c|c|c|}
\hline \multirow{2}{*}{ Items } & \multicolumn{5}{|c|}{ Parameters } \\
\hline & Hardness (gf) & Springiness (mm) & Gumminess (kg/mm) & Chewiness $(\mathrm{kg} / \mathrm{mm})$ & Cohesiveness (ratio) \\
\hline \multicolumn{6}{|c|}{ Treatments ${ }^{11}$} \\
\hline SA & $3,299^{A}$ & $6.42^{\mathrm{A}}$ & $28.1^{\mathrm{A}}$ & $178^{\mathrm{A}}$ & $8.49^{A}$ \\
\hline TSA & $3,318^{A}$ & $6.23^{\mathrm{A}}$ & $27.2^{\mathrm{A}}$ & $168^{A}$ & $8.41^{\mathrm{A}}$ \\
\hline \multicolumn{6}{|l|}{ Days } \\
\hline 3 & $2,971^{b c}$ & $6.27^{\mathrm{a}}$ & $21.9^{b}$ & $129^{\mathrm{bc}}$ & $7.89^{\mathrm{a}}$ \\
\hline 7 & $3,173^{\mathrm{ab}}$ & $6.26^{\mathrm{a}}$ & $26.2^{\mathrm{ab}}$ & $163^{\mathrm{abc}}$ & $8.37^{\mathrm{a}}$ \\
\hline 14 & $2,977^{b c}$ & $6.67^{\mathrm{a}}$ & $27.4^{\mathrm{ab}}$ & $164^{\mathrm{ab}}$ & $8.57^{\mathrm{a}}$ \\
\hline 21 & $3,585^{\mathrm{a}}$ & $6.22^{\mathrm{a}}$ & $32.1^{\mathrm{a}}$ & $210^{\mathrm{a}}$ & $8.72^{\mathrm{a}}$ \\
\hline 28 & $3,529^{\mathrm{ab}}$ & $6.45^{\mathrm{a}}$ & $30.6^{\mathrm{a}}$ & $213^{\mathrm{a}}$ & $8.24^{\mathrm{a}}$ \\
\hline 35 & $3,414^{\mathrm{ab}}$ & $6.48^{\mathrm{a}}$ & $27.1^{\mathrm{ab}}$ & $178^{\mathrm{ab}}$ & $8.03^{\mathrm{a}}$ \\
\hline
\end{tabular}

1) CTL, low fat sausages without film; SA, low fat sausages wrapped with $2 \%$ sodium alginate film; TSA, low fat sausages wrapped with $2 \%$ sodium alginate and $1 \%$ cherry tomato powder film.

${ }^{a-c}$ Mean with a different superscript in the same treatment were different $p<0.05$.

${ }^{A, B}$ Mean with a different superscript in the same storage days were different $p<0.05$. 

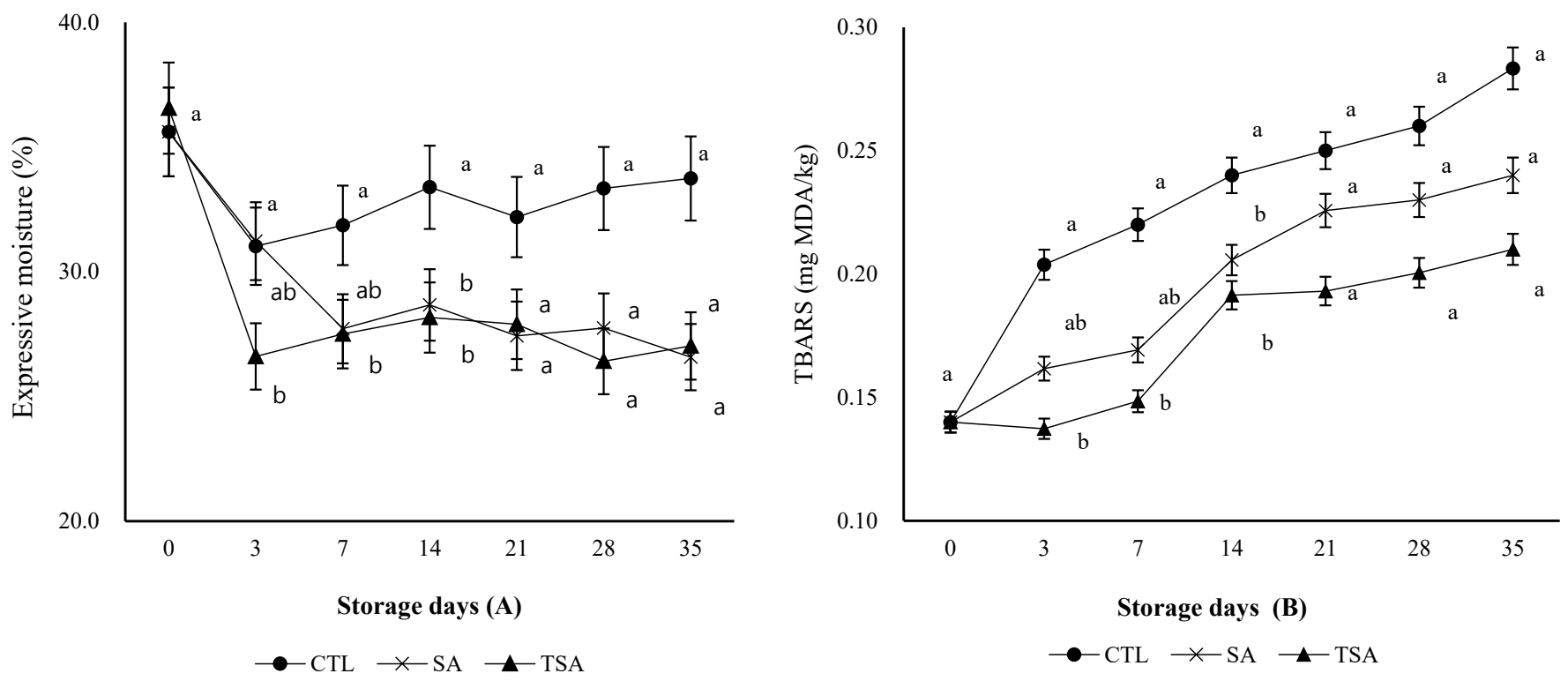

Figure 1. Expressive moisture (A) and thiobarbituric acid reactive substances (B) of low-fat pork saussages and those wrapped with SA and TSA films. EM, expressive moisture; TBARS, thiobarbituric acid reactive substances; CTL, low fat sausages without film; SA, low fat sausages wrapped with 2\% sodium alginate film; TSA, low fat sausages wrapped with $2 \%$ sodium alginate and $1 \%$ cherry tomato powder film. ${ }^{a, b}$ Mean with different superscript on the same day indicate significant differences at $p<0.05$.

life or quality and safety of meat or meat products without changes in sensory characteristics. Although film absorbed water from sausages, it didn't much affect the sausage quality due to the mechanical properties (moisture content, solubility in water, water vapor permeability) of films [24,25]. Alginate coating could reduce microbial counts and form acceptable flavor, tenderness and appearance [26]. Thus, application of films to LFSs might change the textural hardness and may also affect the sensory characteristics.

\section{Microbial counts}

As shown in Table 4, TPCs of treatment covered by TSA film were detected from 28 days of storage days and were found to be lower than CTL and LFSs covered by SA film. The lower microbial count in sausages wrapped with the TSA-film might be attributed to lower $\mathrm{pH}$ value, which resulted in reduced microbial growth. Decreased $\mathrm{pH}$ inhibited the anaerobic growth of enterobacteria and prevented meat spoilage as supported by previous studies. Grau [27] reported that lower $\mathrm{pH}$ value of muscle could support more undissociated lactate, which is an effective inhibitor. Vergara and Gallego [28] studied different compositions of gas present in the package during the 17 days of storage of lamb meat, and reported that $\mathrm{pH}$ values near 5.8 among the lower $\mathrm{pH}$ values favored bacterial growth and meat spoilage, which the relationship between bacteria and $\mathrm{pH}$ value was clearly reported. Another study also reported that modified atmosphere packaging with aloe gel or inclusion of thymol or eugenol enhanced the content of bioactive compounds including phenolics and ly- copene, which in turn reduced the incidence of microbial spoilage [29]. These results indicated that LFSs wrapped with TSA film exhibited antimicrobial effect. It is proposed that TSA film can be used for enhancing the shelf-life of meat products.

Table 4. Microbial counts of low-fat pork sausages wrapped with SA and TSA films

\begin{tabular}{ccc}
\hline \multirow{2}{*}{ Items } & \multicolumn{2}{c}{ Parameters (Log CFU/g) } \\
\cline { 2 - 3 } & TPC & VRB \\
\hline Treatments $^{1)}$ & & \\
CTL & $4.59^{\mathrm{A}}$ & $<2^{\mathrm{A}}$ \\
SA & $4.23^{\mathrm{AB}}$ & $<2^{\mathrm{A}}$ \\
TSA & $3.65^{\mathrm{B}}$ & $<2^{\mathrm{A}}$ \\
Days & & \\
0 & $<2^{\mathrm{b}}$ & $<2^{\mathrm{a}}$ \\
3 & $<2^{\mathrm{b}}$ & $<2^{\mathrm{a}}$ \\
7 & $<2^{\mathrm{b}}$ & $<2^{\mathrm{a}}$ \\
14 & $<2^{\mathrm{b}}$ & $<2^{\mathrm{a}}$ \\
21 & $<2^{\mathrm{b}}$ & $<2^{\mathrm{a}}$ \\
28 & $4.04^{\mathrm{ab}}$ & $<2^{\mathrm{a}}$ \\
35 & $4.28^{\mathrm{a}}$ & $<2^{\mathrm{a}}$ \\
\hline
\end{tabular}

CFU, colony-forming unit; TPC, total plate counts; VRB, violet red bile.

1) $\mathrm{CTL}$, low fat sausages without film; $\mathrm{SA}$, low fat sausages wrapped with $2 \%$ sodium alginate film; TSA, low fat sausages wrapped with $2 \%$ sodium alginate and $1 \%$ cherry tomato powder film.

$a, b$ Mean with a different superscript in the same treatment were different $p<0.05$.

$A, B$ Mean with a different superscript in the same storage days were different $p<0.05$. 
Expressible moisture (\%) and thiobarbituric acid reactive substances

As shown in Figure 1A, EM of LFSs wrapped with TSA film was lowest among the treatments at day 3 and lower than CTL before day 14. Since EM is related to water holding capacity and water activity, and it could be affected by the barrier properties of film such as water absorption [30]. Figure 1B shows the result of TBARS values as affected by LFSs wrapped with different films. The TBARS values of all samples gradually increased during storage and those of LFSs wrapped with TSA film was lower than the CTL $(\mathrm{p}<0.05)$ before day 14 . However, no differences in TBARS between LFSs wrapped with SA film and CTL were observed except for those on day 14 ( $p>0.05$ ). The TBARS value exhibited a gradual increasing tendency and below rancid value (1.0) during or at the end of storage. Thus, LFSs wrapped with TSA film might have antioxidant activity as compared to other treatments. Similar results were accounted for by Siripatrawan and Noipha [31], who reported that pork sausages with green tea film extended shelf-life. During storage, higher TBA was observed in control samples rather than LFSs wrapped with chitosan film and chitosan green tea film due to antioxidant activity of chitosan as well as its lower oxygen permeability characteristic $[31,32]$. These results suggested that lipid oxidation of sausage could be affected by bioactive film and antioxidant grape tomato powder. In this study, antioxidant activity of LFSs wrapped with TSA film showed better results than CTL. Also, it is proposed that TSA film could be used to enhance the antioxidant activities of meat products.

\section{CONCLUSION}

Sausages wrapped with TSA films increased hardness, but decreased protein contents (\%) and $\mathrm{pH}$ values. In addition, reduced lipid oxidation, inhibited microbial growth, and improved water holding capacity were observed in the sausages with the wrapping of TSA, resulting in the extension of shelflife of low-fat meat products during storage. Consequently, TSA films could be applied to meat products to extend the shelf-life in meat industries.

\section{CONFLICT OF INTEREST}

We certify that there is no conflict of interest with any financial organization regarding the material discussed in the manuscript.

\section{ACKNOWLEDGMENTS}

This work was supported by Technology development program (\# PJ013809022018) for rural development administration, republic of Korea.

\section{REFERENCES}

1. Ambrosiadis J, Soultos N, Abrahim A, Bloukas JG. Physicochemical, microbiological and sensory attributes for the characterization of Greek traditional sausages. Meat Sci 2004;66: 279-87. https://doi.org/10.1016/S0309-1740(03)00100-1

2. Gombotz WR, Wee SF. Protein release from alginate matrices. Adv Drug Deliv Rev 1998;31:267-85. https://doi.org/10.1016/ S0169-409X(97)00124-5

3. Kikuchi A, Kawabuchi M, Watanabe A, Sugihara M, Sakurai Y, Okano T. Effect of $\mathrm{Ca}^{2+}$ - alginate gel dissolution on release of dextran with different molecular weights. J Control Release 1999;58:21-8. https://doi.org/10.1016/S0168-3659(98)00141-2

4. Pereira R, Tojeira A, Vaz DC, Mendes A, Bártolo P. Preparation and characterization of films based on alginate and aloe vera. Int J Poly Anal Char 2011;16:449-64. https://doi.org/10. 1080/1023666X.2011.599923

5. Fang YP, Al-Assaf S, Phillips GO, et al. Multiple steps and critical behaviors of the binding of calcium to alginate. J Phys Chem B 2007;111:2456-62. https://doi.org/10.1021/ Jp0689870

6. Boontheekul T, Kong HJ, Mooney DJ. Controlling alginate gel degradation utilizing partial oxidation and bimodal molecular weight distribution. Biomaterials 2005;26:2455-65. https://doi.org/10.1016/j.biomaterials.2004.06.044

7. Caris-Veyrat C, Amiot MJ, Tyssandier V, et al. Influence of organic versus conventional agricultural practice on the antioxidant microconstituent content of tomatoes and derived purees; consequences on antioxidant plasma status in humans. J Agric Food Chem 2004;52:6503-9. https://doi.org/10.1021/ jf0346861

8. Ong ASH, Tee ES. Natural sources of carotenoids from plants and oils. Methods Enzymol 1992;213:142-67. https://doi.org/ 10.1016/0076-6879(92)13118-H

9. Sies H, Stahl W. Vitamins E and C, beta-carotene, and other carotenoids as antioxidants. Am J Clin Nutr 1995;62:1315S21S. https://doi.org/10.1093/ajcn/62.6.1315S

10. Abushita AA, Hebshi EA, Daood HG, Biacs PA. Determination of antioxidant vitamins in tomatoes. Food Chem 1997; 60:207-12. https://doi.org/10.1016/S0308-8146(96)00321-4

11. Soma S, Kalpana K. Nutritional content and significance of tomato powder. Ann Arid Zone 2013;52:121-4.

12. Goula AM, Adamopoulos KG. Stability of lycopene during spray drying of tomato pulp. LWT-Food Sci Technol 2005; 38:479-87. https://doi.org/10.1016/j.lwt.2004.07.020

13. Goula AM, Adampoulos KG, Chatzitakis PC, Nikas VA. Prediction of lycopene degradation during a drying process of tomato pulp. J Food Eng 2006;74:37-46. https://doi.org/10. 1016/j.jfoodeng.2005.02.023

14. Fernández-Pan I, Carrión-Granda X, Maté JI. Antimicrobial efficiency of edible coatings on the preservation of chicken breast fillets. Food Control 2014;36:69-75. https://doi.org/ 
10.1016/j.foodcont.2013.07.032

15. Bingol EB, Bostan K. Effect of sodium lactate on the microbiological quality and shelf life of sausages. Turk J Vet Anim Sci 2007;31:333-9.

16. Patricia C. AOAC International. Official methods of analysis of AOAC International. 16th ed. Gaithersburg, MD, USA: AOAC International; 1995.

17. Bourne MC. Texture profile analysis. Food Technol 1978;36: 62-66,72.

18. Shinnhuber RO, Yu TC. The 2-thiobarbituric acid reaction, an objective measure of the oxidative deterioration occurring in fats and oils. J Japan Oil Chem Soc 1977;26:259-67. https://doi.org/10.5650/jos1956.26.259

19. Deda MS, Bloukas JG, Fista GA. Effect of tomato paste and nitrite level on processing and quality characteristics of frankfurters. Meat Sci 2007;76:501-8. https://doi.org/10.1016/j. meatsci.2007.01.004

20. Yuan C, Lv H, Yang B, Chen X, Sun H. Physical properties, antioxidant and antimicrobial activity of chitosan films containing carvacrol and pomegranate peel extract. Molecules 2015;20:11034-45. https://doi.org/10.3390/molecules2006 11034

21. Candogan K. The effect of tomato paste on some quality characteristics of beef patties during refrigerated storage. Eur Food Res Technol 2002;215:305-9. https://doi.org/10.1007/s00217002-0567-1

22. Elbakheet IS, Elgasim AE, Algadi MZ. Proximate composition of beef sausage processed by wheat germ flour. J Food Process Technol 2017;8:11. https://doi.org/10.4172/2157-7110.1000 704

23. Ruiz-Ramírez J, Arnau J, Serra X, Gou P. Relationship between water content, $\mathrm{NaCl}$ content, $\mathrm{pH}$ and texture parameters in dry-cured muscles. Meat Sci 2005;70:579-87. https://doi.org/ 10.1016/j.meatsci.2005.02.007

24. Sánchez-Ortega I, García-Almendárez BE, Santos-López EM, Amaro-Reyes A, Barboza-Corona JE, Regalado C. Antimicro- bial edible films and coatings for meat and meat products preservation. Sci World J 2014;2014:Article ID 248935. https:// doi.org/10.1155/2014/248935

25. Feng Z, Li L, Wang Q, et al. Effect of antioxidant and antimicrobial coating based on whey protein nanofibrils with $\mathrm{TiO} 2$ nanotubes on the quality and shelf life of chilled meat. Int J Mol Sci 2019;20:1184. https://doi.org/10.3390/ijms2005 1184

26. Cutter CN. Opportunities for bio-based packaging technologies to improve the quality and safety of fresh and further processed muscle foods. Meat Sci 2006;74:131-42. https:// doi.org/10.1016/j.meatsci.2006.04.023

27. Grau FH. Inhibition of the anaerobic growth of Brochothrix thermosphacta by lactic acid. Appl Environ Microbiol 1980; 40:433-6.

28. Vergara H, Gallego L. Effects of gas composition in modified atmosphere packaging on the meat quality of Spanish Manchega lamb. J Sci Food Agric 2001;81:1353-7. https://doi.org/ 10.1002/jsfa.953

29. Mirdehghan SH, Valero D. Bioactive compounds in tomato fruit and its antioxidant activity as affected by incorporation of Aloe, eugenol, and thymol in fruit package during storage. Int J Food Prop 2017;20:1798-806. https://doi.org/10.1080/ 10942912.2016.1223128

30. Othman SH, Edwal SAM, Risyon NP, Basha RK, Talib R. Water sorption and water permeability properties of edible film made from potato peel waste. Food Sci Technol 2017; 37:63-70.

31. Siripatrawan U, Noipha S. Active film from chitosan incorporating green tea extract for shelf life extension of pork sausages. Food Hydrocoll 2012;27:102-8. https:/doi.org/10.1016/ j.foodhyd.2011.08.011

32. Park P, Je J, Kim S. Free radical scavenging activities of differently deacetylated chitosans using an ESR spectrometer. Carbohydr Polym 2004;55:17-22. https://doi.org/10.1016/ j.carbpol.2003.05.002 